\title{
The Effects of Audience's Attitudes on Actor, Character, Movie and Product Placement on the Brand Attitude
}

\author{
Elif Ülker-Demirel1 @ E Erkan Yıldı2²
}

\begin{abstract}
In recent years, there has been a shift in consumers' media consumption preferences from traditional to digital platforms. Adblocker applications used by consumers who do not want to be exposed to advertising and the digital platforms that offer ad-free content make it increasingly difficult for brands to reach audiences in a highly saturated advertising environment. In this environment, product placement remains essential in reaching the target audiences due to the advantages it offers to brands compared to traditional advertisements. The aim of this study, being distinctly different from previous research, is to test the effects of attitude toward actor and character on attitude toward movies, product placement, and brand. Furthermore, it is aimed to investigate the serial mediating effect between these attitudinal constructs. The data obtained from 300 participants were analyzed with SmartPLS 3.2.8 using partial least squares path analysis (PLS-SEM). As a result, the attitude toward the actor, character, and movie has direct and indirect effects on product placement and attitude toward the brand. Furthermore, the effect of the attitude toward movies and product placement has a serial mediating effect on the relationship between the attitude toward the actor, the character and the brand.
\end{abstract}

Keywords

Product Placement, Attitude, Actor, Brand, PLS-SEM

\section{Introduction}

Traditional advertising media and messages are skipped without being watched by consumers, therefore making it challenging to reach target consumers. Considering today's consumers, who have a low average attention span, want to access the content they want to watch quickly and smoothly, and skip what they are not interested in without watching it, product placements in videos, movies, and TV series have become more critical and preferred for brands. People can choose whether or not to consume ads, just like products (Tuchman, WenKo, \& Liu, 2018).

According to Deloitte's research on ad-blocking behaviors of audiences on various platforms in 2017 (Deloitte, 2017), approximately three-quarters of Americans use at least one

1 Corresponding author: Elif Ülker Demirel (Asst. Prof. Dr.), Trakya University, Faculty of Applied Sciences, Edirne, Turkey. E-mail: elifulker@ trakya.edu.tr ORCID: 0000-0002-5805-0452

2 Erkan Yıldız (Asst. Prof. Dr.), Başkent University, Kahramankazan Vocational School, Kahramankazan, Ankara, Turkey. E-mail: eyildiz@ baskent.edu.tr ORCID: 0000-0002-4565-779X

To cite this article: Ulker-Demirel, E., \& Yildiz, E. (2020). The Effects of Audience's Attitudes on Actor, Character, Movie and Product Placement on the Brand Attitude. Istanbul Business Research, 49(2), 339-359. http://doi.org/10.26650/ibr.2020.49.0013 
ad-blocker app, while a smaller subset of about $10 \%$ - which is called "adlergic", a combination of two words, "advertising" and "allergic" - often block ads on platforms in four or more traditional and digital media. When the findings of traditional TV advertising were examined, about $50 \%$ of the participants in the United States and Canada stated that there was a fast-forward feature on their televisions and they used it. However, those who do not have TVs with this feature stated that they changed the channel, muted it, left the room or looked at their phones, computers or tablets. When this is examined specifically with regards to Turkey, approximately more than $60 \%$ of the participants expressed that they changed the TV channel. For the sampling of all three countries, these rates indicate that the young population (aged 18-34) tends to be much more "adlergic" (Deloitte, 2017).

According to the Association of Advertising Agencies' report on Media and Advertising Investments in Turkey, advertising and media investments increased by $2.9 \%$ to 11 Billion TL as of 2018 (Association of Advertising Agencies, 2018). Looking at these figures, particularly for the World and Turkey, it can be said that a significant proportion of these expenditures are directed to digital channels rather than traditional ads. Therefore, the changing trends in general advertising expenditure in the world has caused the change of the platforms the brands preferred to use in the product placement category. In the United States, the product placement market in live and video-on-demand (VOD) television platforms and digital videos increased by $13.7 \%$ to 8.78 Billion Dollars as of 2017 (PQ Media, 2018).

Product placement, which is defined as a combination of advertising and promotion designed to impress the audience by adding branded products without attracting attention on platforms such as movies and TV series, without being aware of the intention of persuading the audience (Balasubramanian, 1994), has continued to be seen as an attractive tool different from traditional means of communication, used in order to change the attitudes mentioned above of the audience, raise brand awareness, recall and, most importantly, affect buying behaviors positively.

The potential effects of product placement in movies and TV series, such as affecting the audience's attitudes, increasing their awareness toward brands, enriching and differentiating brand experiences, are explained by drawing on various theories in the literature. (Balasubramanian, et al., 2016). The Meaning Transfer Model (McCracker, 1989), one of the theories explaining the relationship between product placement and actor and audience in films, explains the transfer of the cultural meanings from actors or celebrities to products and from products to audiences. However, the characters that actors play are just as important as the actors or actresses to explain the relationship between the audience and the products placed in movies. Horton and Whol's (1956) The Parasocial Interaction Theory describes the one-way emotional relationship that the audience develops over time with famous actors or characters in movies or TV series. This relationship increases the emotionally parasocial effect of brands associated with characters represented in a positive context in movies and creates a positive 
brand perception (Knoll vd., 2015: 740). Therefore, there seems to be an interaction between the actors/characters in movies and TV series and the brands placed in them.

Therefore, the present study aims to test the effects of consumers' attitudes toward actors and characters on their attitudes toward movies, product placement, and brands, and investigate the serial mediation effects between these attitudinal variables. To suit the purpose of the study, the relations between consumers' attitudes toward actors/actresses and the characters they play, the attitudes toward a movie, the attitudes toward product placement and brand are explained. There are numerous studies published in relation to the product placement practices in different communicational and cultural tools such as movies, TV series and literature and their effect on buying behaviors of individuals (Jin \& Villegas, 2007; McKechnie \& Zhou, 2003; Barnhardt, Manzano, Brito, Myrick, \& Smith 2016), brand recall (Johnstone \& Dodd, 2000; Argan, Velioğlu, \& Argan, 2007) and the attitudes of the audience (Balasubramanian, Karrh \& Patwardhan, 2006; Russell \& Stern, 2006; Philips, \& Noble, 2007; Cowley \& Barron, 2008; Sapmaz \& Tolon, 2014; Kurcova \& Şirin, 2017). However, there seems to be a scarcity of research focusing on other attitudinal components affecting the audience's attitudes toward product placement, to the best of the authors' knowledge. This research, which was addressed within the framework of Balasubramanian, Patwardhan, Pillai, \& Coker's (2014) research on the components that affect the audience's attitudes, aimed to fill the gap in the literature and explain the other attitude components behind the audience's attitudes toward the brands involved in product placement.

\section{Literature Review}

\section{Product Placement}

Product placement, which can be defined as a paid product message in which a trademarked product, product package or logo is placed in a movie or television program in a planned and inconspicuous way to impress the audience (Balasubramanian, 1994), began in the 1930s when American tobacco companies first made payment to movie stars to show their support for their brands (McKechnie \& Zhou, 2003).

Product placement, which is the inclusion of branded products and services in mass media (Newell, Salmon, \& Chang, 2006), has significantly become a highly preferred practice for marketing professionals and brands in recent years, especially through the increasing diversity in television programs and digital platforms that offer the opportunity to watch movies and TV series over the Internet.

Unlike cable television platforms, Over-the-Top (OTT) viewing, which is referred to as movie or television content that is accessed through a fast Internet connection and does not require any subscription, has become popular especially with applications such as Netflix and 
Apple TV as an important platform in this field. The fact that these platforms provide ad-free content is one of the most important reasons for preference for the audience, but it also eliminates the possibility of reaching the audience through television ads by marketing professionals. Therefore, the changing of the audience's media content consumption and streaming platform preferences (Ulker-Demirel, Akyol, \& Gölbaşı Şimşek, 2018) has led to a significant change in the direction of the advertising content from traditional media to digital platforms. Along with these platforms offering ad-free content, developments in various media formats have led marketing professionals to prefer alternative advertising forms such as product placement rather than traditional ads. Since the transformation of the audience's habits of entertainment content consumption has changed due to developments in various media formats, marketing professionals face new challenges in the context of brand management strategies (Kim \& Shin, 2017).

However, in today's saturated advertising media, hybrid messages such as product placement (Balasubramanian, 1994), may be stronger than traditional ads unless they are perceived by consumers as persuasive messages (Russell, 2002). Therefore, product placement is largely used in the promotion of products through the development / acquisition of individual attitudes of the audience (Su, Huang, Brodowsky, \& Kim, 2011). Moreover, the audience, who decides whether or not to watch the ad content in traditional ads, is exposed to and unable to escape the existing content if there is product placement in a movie or TV series. This reveals the most important difference of product placement from traditional advertising tools.

There is an accumulation of literature and an increasing interest in product placement in the literature. Notwithstanding that the current research is based on the recall of the brand being placed (Scott \& Craig-Less, 2010; Argan, et al., 2007), consumer attitudes toward the brand (Kırcova \& Köse, 2017; Sapmaz \& Tolon, 2014), consumer purchase intentions and the effectiveness of product placement (Karrh, Firth, \& Callison, 2003; Williams, Petrosky, Hernandez, \& Page, 2011), there are also studies on cross-cultural comparisons to examine audience attitudes (McKechnie \& Zhou, 2003) and the concepts of reverse product placement (Muzellec, Kanitz, \& Lynn 2013; Patwardhan \& Parwardhan, 2016).

Balasubramanian et al. $(2006 ; 2014)$ evaluated the attitudes of the audience toward product placement and the factors that could shape the effectiveness of product placement in two categories: stimulus/execution related (prominence, repetition, placement method) and individual difference related (attitude toward practice, specific placement sections, media platform in which the brand is placed, perception of the harmony of the character played by the actor/actress and the product). Since this research focuses on elements that may affect the audience's attitudes and are differentiated individually, the attitude toward the brand will be examined within the framework of the attitudes toward the actor/actress, character, movie, and product placement. Therefore, the effects of attitude toward actor and character on movies, product placement, and finally, brand attitude will be explained, and serial mediation effects between these attitudinal variables will be analyzed. 


\section{Product Placement and Attitudinal Constructs}

Product placement, which is considered as a form of advertising, has a commercial meaning and content (Tsai, Wen-Ko, \& Liu, 2007; Balasubramanian et al., 2014). Research shows that consumers who have a positive attitude toward advertising, in general, are generally also positive to the advertised brand (MacKenzie \& Lutz, 1989). When the audience's attitudes toward product placement were examined, it was seen that they enjoy product placements in movies and TV series because it increased realism, helped in character development, created historical subtexts, and developed familiarity (Nelson \& Devanatan, 2006). It is very likely that audiences which show a positive approach to product placement in movies as well as movies where it can be realistically incorporated into the scenario and processed inconspicuously will exhibit positive attitudes toward products for specific product categories. However, this attitude may differ when it comes to products that are considered unethical and need to be restricted, such as cigarettes and alcohol (Gupta \& Gould, 1997). Therefore, the attitudes of the audience toward product placement vary according to the media used, target audience and product/service type (Karrh, Mckee, \& Pardun, 2001).

Movies as experiential products are considered as brands, because movie sequels are evaluated in the context of brand expansion (Sood \& Dreze, 2006). Because movies -like commercial products- have a symbolic dimension, capital, and technological investment, they are released to the market, have intellectual and civil rights, differentiate themselves from other movies, have a strategic asset, and brand value within the brand portfolios of the production companies, for example, the Harry Potter series, The Lord of the Rings Trilogy, Iron Man in Marvel movies, and so on. They are also the values by which 'brand value' can be calculated with box-office returns and by-product revenues, and by which the awareness of the movie brand and recall items can be discussed (O'Reilly \& Kerrigan, 2013). Based on these findings, therefore, it is possible to predict that movies as a brand have the potential to affect the attitudes of the audience toward the product placement and the brand being placed.

The attitudes of the audience toward the movie in the literature are significantly and positively related to the prominence of the placement of the brand in the movie in which it appears (Johnstone \& Dodd, 2000). Besides, it is predicted that directors and actors/actresses have a significant impact on the creation of the movie brand that in turn can shape the attitude toward the movie. The reason for this is that movies are seen as a brand, which are complex experiential products where the talent and reputation of many elements such as directors, actors, producers, and movie studios come together (Balasubramanian et al., 2014).

\section{Attitude Toward Actress / Actor}

In the literature, the audience's interactions with the actor/actress and the character, which have an impact on shaping their attitudes toward the brand in product placement, are explained 
within the framework of the meaning transfer model and parasocial theory (Balasubramanian, et al., 2006; Balasubramanian et al., 2014). McCracken's (1989) meaning transfer model has been used many times in the literature to explain the use of celebrities in advertising mediums and consumer responses to product placement (Russell, 1998; Kurthakoti, Balasubramanian, \& Altobello, 2016). According to McCracken, meaning begins as an established element in the physical and social world, which is constituted with the principles of the culturally dominant culture. Along with the introduction of the generated meaning in the consumer goods, it becomes a part of the daily lives of consumers. Factors such as advertising and fashion play an important role in this transfer between culture, commercial products and consumers. The transfer process begins with deciding which cultural meanings (lifestyle, gender, and so on) or, in its simplest terms, which message should be delivered with the relevant product. It is a bidirectional model that plays a role in transferring the correct meaning both from the actor/ actress/celebrity in the movie to the relevant product, and the product to the actor/actress, and thus establishing effective communication with the audience (Balasubramanian et al., 2006).

The meaning transfer model, as a method that can explain the reactions of the audience toward product placement (Srivastava, 2011), is important not only for transferring other attitudinal components that affect the attitudes of the audience toward a brand placed in the movie, but also for the audience to watch content more carefully than traditional ads, and also to be able to naturally transfer the actor/actress's relationship with the placed product by incorporating it into the scenario (Balasubramanian et al., 2014).

\section{Attitude Toward Character}

Horton and Wohl (1956) mention a unilateral interpersonal relationship that develops between the audience and the characters on television with parasocial interaction. According to the parasocial theory, the audience develops an affinity and attitude toward the character of the actor/actress in the television programs they watch, and their predictability for that character begins to increase over time (Rubin \& McHugh, 1987). The audience begins to recognize and become familiar with those characters, just like their friends, through their appearance, voice, mimics and behaviors over time (Horton \& Wohl, 1956).

In terms of product placement, parasocial interaction causes the audience to identify themselves with them and to use them as a model for the right product selection as they get closer to the characters (Russell \& Stren, 2006). Therefore, in the light of the parasocial interaction literature, the character of the actor/actress is expected to affect the attitude toward the movie and the TV series and indirectly toward the product placement and the attitude toward the brand where the product placement takes place. 


\section{Methodology}

The previous studies on product placement in the literature often focused on the purchasing intentions of the audience (Karrh, Firth, \& Callison, 2003; Jin \& Villegas, 2007), their attitudes to product placement (Russell \& Stern, 2006; Cowley \& Barron, 2008), and the effect of product placement on the attitudes of the audience toward a brand (K1rcova \& Köse, 2017). However, there may be some other factors influencing people's attitudes and behaviors toward product placement. The meaning transfer model suggests that the audience's attitudes toward brands can be influenced by the interactions between audiences, brands, and the celebrities with whom the audience interacts (McCracker, 1989). Similarly, the parasocial interaction theory posits that the audience's attitudes toward actors and characters in movies or TV series may be influenced by the emotional relationship they develop over time. Drawing from these two theories, the celebrities in movies and TV series, the characters they play, and the audience seem to be closely linked to the audience's attitude toward the movies because the actors and the characters they play affect the audiences' movie preferences to a great extent (Ulker-Demirel et al., 2018). Therefore, we hypothesize that the attitudes toward actors and characters could affect the attitudes toward the movie, the product placement in the movie, and, thus, the brand.

\section{Conceptual Model and Hypotheses Development}

As a result of the current literature review, the research model and hypotheses based on the variables used in the literature in accordance with the purpose of the research are given below.

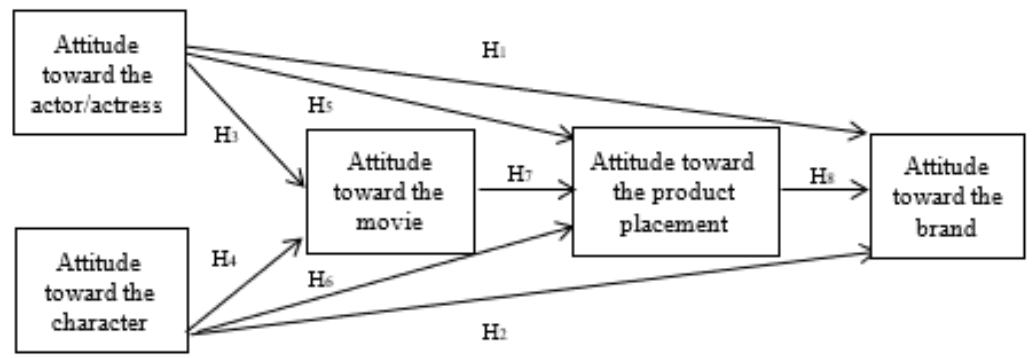

Figure 1. Research Model

$\mathbf{H}_{1}$ : Attitude toward the actor/actress has a positive effect on attitude toward the brand

$\mathbf{H}_{2}$ : Attitude toward the character has a positive effect on attitude toward the brand 
$\mathbf{H}_{3}$ : Attitude toward the actor / actress has a positive effect on attitude toward the movie

$\mathbf{H}_{4}$ : Attitude toward the character has a positive effect on attitude toward the movie

$\mathbf{H}_{5}$ : Attitude toward the actor / actress has a positive effect on attitude toward the product placement

$\mathbf{H}_{6}$ : Attitude toward the character has a positive effect on attitude toward the product placement

$\mathbf{H}_{7}$ : Attitude toward the movie has a positive effect on attitude toward the product placement

$\mathbf{H}_{8}$ : Attitude toward the product placement has a positive effect on attitude toward the brand

$\mathbf{H}_{9}$ : Attitude toward the movie and attitude toward product placement have a serial mediating effect on the relationship between attitude toward the actor/actress and attitude toward the brand.

$\mathbf{H}_{10}$ : Attitude toward the movie and attitude toward product placement have a serial mediating effect on the relationship between attitude toward the character and attitude toward the brand.

\section{Measurement of Constructs}

Studies in the literature were used to measure the variables of the research. The attitude toward the actor was taken from Ohanian's (1990) study and measured 15 items, while the attitude toward the movie was taken from d'Astous \& Touil's (1999) study and used 4 items. For attitudinal variables toward the character, brand and product placement, Balasubramanian et al.'s (2014) study was used and they were measured using 5, 4 and 4 items, respectively.

\section{Sample and Procedure}

This study aimed to connect with audiences who watch movies/TV series. Participants, who are young people watching movies/TV series at least once a week, were recruited because young audiences' subscription rates, particularly in the $\mathrm{X}$ and $\mathrm{Y}$ generations, to platforms such as online and paid channels, and the rates of movie and series watching are higher than the older groups (Iqbal, 2020; Westcott et al., 2020; Balasubramanian et al., 2014). Therefore, undergraduate and graduate students with different demographic backgrounds made up the sample of the study. Due to population size, time, and cost constraints, the research data was instantly collected using the non-probability convenience sampling technique. 
A survey, which included closed-end and pre-prepared questions, was used as the data collection method in the research. The survey consisted of three sections and 40 questions. In the first section, the participants were asked to specify the name of the movie/TV series they had watched in the last week, the brand name they remember, and the sector to which the brand belongs, as well as the name of the actor/actress appearing with the brand. The reason for the limitation to the last week was to enable them to answer the questions correctly in the first section and then to answer other questions on the basis of their responses in this first section. In addition, it is not possible for individuals who have been exposed to product placement to be able to remember the brand for a long time, and therefore the data should be collected within a very short period of time after product placement (Mackay, Ewing, Newton, \& Windisch, 2009; Balasubramanian et al., 2014). The second section included 32 items measuring the variables of the research. The participants were asked to evaluate the questions in the survey on the basis of the items with a 5-point semantic differential scale for the items measuring the attitude toward the actor/actress, character, brand, product placement, and the attitude toward the movie. In the last section, their age, gender, education and frequency of watching movies were asked.

The survey was conducted between 15 April and 15 June 2019. Of the 500 face-to-face and online surveys distributed, 357 were answered and returned. The rate of return was $71.4 \%$. The participants were expected to answer the questions completely in the first section of the survey, including the name of the movie/TV series they had watched, the brand name that stuck in their mind, the sector to which the brand belongs, and the name of the actor/actress. In this section, 300 useable surveys were obtained due to the exclusion of those with missing requested information. However, the information obtained was verified from multiple sources, through both movie sites and the website available for the movie or TV series, in order to ensure the accuracy of the movie, brand, sector and actor/actress specified in the surveys for the reliability of the research (e.g. IMDB, sinemalar.com, beyazperde.com). Of the participants, $46.3 \%$ were female $(\mathrm{N}=139)$ and $53.7 \%$ were male $(\mathrm{N}=161), 67.7 \%$ were between the ages of $18-24(\mathrm{~N}=203), 85 \%$ were doing an undergraduate degree $(\mathrm{N}=255), 42.3 \%$ of the subjects who participated in the research watched movies/TV series several times a week.

\section{Results}

\section{Measurement Model}

Before the analysis of the research model, internal consistency reliability, convergent validity, and discriminant validity were evaluated. For internal consistency reliability, Cronbach's alpha and composite reliability (CR) coefficients were examined. The average-variance-extracted (AVE) values by factor loadings were used to determine convergent validity. 
Therefore, factor loadings as $\geq 0.70$, Cronbach's Alpha and composite reliability coefficients as $\geq 0.70$ and also average-variance-extracted value as $\geq 0.50$ were expected (Hair, Black, Babin, Anderson, \& Tatham, 2006; Hair, Tomas, Hult, Ringle, \& Sarstedt, 2014; Fornell \& Larcker, 1981). The results of the constructs within the scope of the research for internal consistency reliability and convergent validity are given in Table 1.

Table 1

Measurement Model Estimates

\begin{tabular}{|c|c|c|c|c|c|}
\hline Construct & Items & Factor Loadings & Cronbach Alpha & CR & AVE \\
\hline \multirow{10}{*}{$\begin{array}{l}\text { Attitude toward the Actor/ } \\
\text { Actress }\end{array}$} & ATA6 & 0.737 & 0.894 & 0.912 & 0.511 \\
\hline & ATA7 & 0.773 & & & \\
\hline & ATA8 & 0.742 & & & \\
\hline & ATA9 & 0.760 & & & \\
\hline & ATA10 & 0.778 & & & \\
\hline & ATA11 & 0.674 & & & \\
\hline & ATA12 & 0.665 & & & \\
\hline & ATA13 & 0.674 & & & \\
\hline & ATA14 & 0.709 & & & \\
\hline & ATA15 & 0.616 & & & \\
\hline \multirow{5}{*}{$\begin{array}{l}\text { Attitude toward the char- } \\
\text { acter }\end{array}$} & ATC1 & 0.813 & 0.847 & 0.891 & 0.621 \\
\hline & ATC2 & 0.807 & & & \\
\hline & ATC3 & 0.801 & & & \\
\hline & ATC4 & 0.786 & & & \\
\hline & ATC5 & 0.729 & & & \\
\hline \multirow[t]{4}{*}{ Attitude toward the movie } & ATM1 & 0.903 & 0.910 & 0.937 & 0.789 \\
\hline & ATM2 & 0.810 & & & \\
\hline & ATM3 & 0.932 & & & \\
\hline & ATM4 & 0.903 & & & \\
\hline \multirow{4}{*}{$\begin{array}{l}\text { Attitude toward the product } \\
\text { placement }\end{array}$} & ATP1 & 0.894 & 0.856 & 0.904 & 0.703 \\
\hline & ATP2 & 0.920 & & & \\
\hline & ATP3 & 0.815 & & & \\
\hline & ATP4 & 0.711 & & & \\
\hline \multirow[t]{4}{*}{ Attitude toward the brand } & ATB1 & 0.912 & 0.916 & 0.941 & 0.799 \\
\hline & ATB2 & 0.903 & & & \\
\hline & ATB3 & 0.924 & & & \\
\hline & ATB4 & 0.834 & & & \\
\hline
\end{tabular}

According to Hair et al. (2014), factor loadings should be $\geq 0.70$. The authors suggest that items with factor loadings below 0.40 should be excluded from the measurement model and items with factor loadings between 0.40 and 0.70 should be excluded from the measurement model in cases of an increase in AVE or CR values. Therefore, items 4 and 5 of the attitudes toward the actor/actress with factor loadings below 0.40 and the items 1, 2, and 3 of AVE values with the same scale below the threshold value were excluded from the measurement model. Since the calculated AVE and CR values were higher than the threshold values after the items were removed, the other items with a factor loading below 0.708 were not excluded 
from the scale. It can be stated that the internal consistency reliability of the constructs was demonstrated because the Cronbach's Alpha coefficients are between 0.847 and 0.916 , and the CR coefficients are also between 0.891 and 0.941 . When the values in the table were examined, it is possible to state that convergent validity was demonstrated, since the factor loadings were between 0.616 and 0.932 , and the AVE values were between 0.511 and 0.799 . The mean scores of constructs ranged from 3.95 (attitude toward product placement) to 4.35 (attitude toward the movie). It can be stated that the participant perceptions toward the research constructs were generally higher than the average value (according to a 5-point Likert). The descriptive statistics of constructs are illustrated in the table given in Appendix A.

The criteria proposed by Fornell \& Larcker (1981) and the Heterotrait-Monotrait Ratio (HTMT) criteria proposed by Henseler, Ringle, \& Sarstedt (2015) were considered in order to determine the discriminant validity. According to Fornell \& Larcker's (1981) criteria, the square root of the AVE values of the constructs in the research should be greater than the correlations between the construct in the research. Therefore, Table 2 shows the analysis results according to Fornell \& Larcker's (1981) criteria.

Table 2

Comparison of Square Roots of AVE's and Correlations to Assess Discriminant Validity

\begin{tabular}{lccccc}
\hline & ATM & ATC & ATB & ATA & \\
\hline ATM & $(0.888)$ & & & & \\
ATC & 0.357 & $(0.788)$ & & & \\
ATB & 0.225 & 0.469 & $0.894)$ & $(0.715)$ & $(0.839)$ \\
ATA & 0.351 & 0.454 & 0.468 & 0.440 & 0.601 \\
ATP & 0.393 & 0.478 & & & \\
\hline
\end{tabular}

The values in parentheses in Table 2 are the square root values of AVE. When these values were examined, the square root of average-variance-extracted of each construct was higher than its correlation with other constructs.

According to Henseler, et al.,'s (2015) criteria, HTMT expresses the ratio of the average of the correlations of items of all variables in the research (the heterotrait-hetero-method correlations) to the geometric means of the correlations of items of the same variable (the monotrait-hetero-method correlations). The authors stated that the value of HTMT should be less than 0.90 , but it should be below 0.85 as content for the concepts far away from each other. HTMT values are summarized in Table 3. 
Table 3

Values of discriminant validity according to HTMT Criteria

\begin{tabular}{llllll}
\hline & ATM & ATC & ATB & ATA & ATP \\
\hline ATM & & & & \\
ATC & 0.400 & & & \\
ATB & 0.243 & 0.529 & 0.508 & \\
ATA & 0.391 & 0.522 & 0.666 & 0.481 \\
ATP & 0.450 & 0.551 & & \\
\hline
\end{tabular}

When Table 3 is examined, it is seen that HTMT values were below the threshold value. Based on the findings in Table 2 and Table 3 , it is possible to say that the discriminant validity was determined.

\section{Structural Model}

The structural equation modeling developed to test the hypotheses of the research is shown in Figure 2.

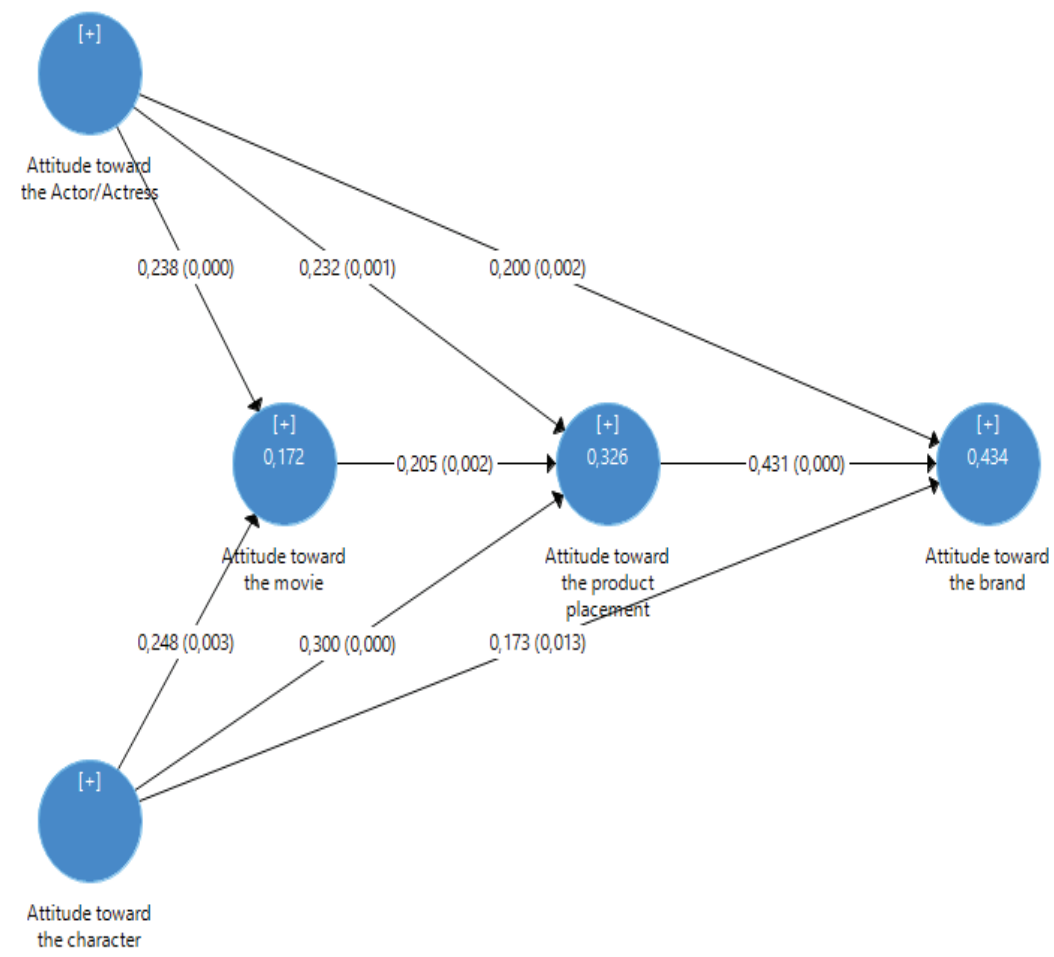

Figure 2. Structural Model 
The partial least squares structural equation modeling (PLS-SEM) was used to analyze the research model, and the data obtained were analyzed using SmartPLS 3.2.8 statistical program (Ringle, Wende, \& Becker, 2015). It was preferred to use PLS-SEM, as the existence of two mediator variables in the research model and the serial mediation effect were wanted to be tested. As part of the research model, the PLS algorithm was used for calculating linearity, path coefficients, $\mathrm{R}^{2}$, and effect size $\left(\mathrm{f}^{2}\right)$ and Blindfolding analysis for estimating power $\left(\mathrm{Q}^{2}\right)$. Bootstrapping was used to assess the significance of the PLS path coefficients and to take 5000 subsamples for the sample to calculate their t-values. The $\mathrm{R}^{2}, \mathrm{f}^{2}, \mathrm{Q}^{2}$, and VIF values of the research results are given in Table 4.

Table 4

The Results of the $R^{2}, f^{2}$ and $Q^{2}$

\begin{tabular}{lccccc}
\hline Constructs & & VIF & $\mathbf{R}^{2}$ & $\mathbf{f}^{2}$ & $\mathbf{Q}^{\mathbf{2}}$ \\
\hline ATA & ATM & 1.260 & 0.172 & 0.054 & 0.122 \\
ATC & & 1.260 & & 0.059 & 0.211 \\
ATA & ATP & 1.328 & 0.326 & 0.060 & \\
ATC & & 1.334 & & 0.100 & \\
ATM & & 1.208 & & 0.052 & 0.321 \\
ATA & ATB & 1.371 & 0.434 & 0.052 & \\
ATC & & 1.433 & & 0.037 & \\
ATP & & 1.410 & & 0.233 & \\
\hline
\end{tabular}

When the VIF (Variance Inflation Factor) values between variables were examined, it was seen that they had a threshold value below 5 , so there was no collinearity issue among the constructs (Hair et al., 2014).

When the $\mathrm{R}^{2}$ values of the model were examined, it was found that the attitude toward the movie was explained as $17 \%$, the attitude toward product placement as $33 \%$, and the attitude toward the brand as $43 \%$. For the effect size coefficient ( $\left.\mathrm{f}^{2}\right), \geq 0.02$ was considered as low, $\geq$ 0.15 as medium and $\geq 0.35$ as high (Cohen, 1988). Sarstedt, Ringle, \& Hair (2017) also stated that there was an effect in cases where the coefficient was less than 0.02 . When the effect size coefficient ( $\mathrm{f}^{2}$ ) was examined, it was found that the attitude toward the actor/actress and character had a low effect on the attitude toward the movie, the attitude toward the actor/actress, character and movie had a low effect on the attitude toward product placement, the attitude toward the actor/actress and character had a low effect on the attitude toward the brand, and the attitude toward product placement had a medium effect on the attitude toward the brand.

When the calculated estimating power coefficients of the endogenous variables $\left(Q^{2}\right)$ are greater than 0 , it shows that the research model has an estimating power for the endogenous variables (Hair et al., 2014). As the $\mathrm{Q}^{2}$ values in Table 4 are greater than 0 , it can be stated that 
the research model has the estimating power for the attitudinal variables toward the movie, product placement and brand.

Table 5 shows the results of hypothesis testing and structural relationships. The model was tested by excluding the mediating variables from it to calculate the total effect of the attitude toward the actor/actress and character on the attitude toward the brand. As a result of the test, it was found that there was an effect of the attitude toward the actor/actress on the attitude toward the brand $(\beta=0.327 ; \mathrm{p}<0.01)$ and the attitude toward the character on the attitude toward the brand $(\beta=0.324 ; p<0.01)$. Based on this result, hypotheses $\mathrm{H}_{1}$ and $\mathrm{H}_{2}$ of the research were supported.

In the second stage, the mediating variables were included in the model to test the significance of the path coefficients. It was seen that there were significant effects of the attitude toward the actor/actress $(\beta=0.238 ; \mathrm{p}<0.01)$ and character $(\beta=0.248 ; \mathrm{p}<0.01)$ on the attitude toward the movie, the attitude toward the actor/actress $(\beta=0.232 ; p<0.01)$, character $(\beta=0.300$; $\mathrm{p}<0.01)$ and movie $(\beta=0.205 ; \mathrm{p}<0.01)$ on the attitude toward product placement, and the attitude toward product placement on the attitude toward the brand $(\beta=0.431 ; \mathrm{p}<0.01)$. In the light of these findings, hypotheses $\mathrm{H}_{3}, \mathrm{H}_{4}, \mathrm{H}_{5}, \mathrm{H}_{6}, \mathrm{H}_{7}$, and $\mathrm{H}_{8}$ of the research were supported.

Table 5

The Results of Hypothesis Testing and Structural Relationships

\begin{tabular}{|c|c|c|c|c|c|}
\hline Constructs & Standardize $\beta$ & Std. Deviation & t Value & $\mathbf{p}$ & \%95 Confidence Int. \\
\hline $\mathrm{H}_{1}: \mathrm{ATA} \triangle \mathrm{ATB}$ & 0.327 & 0.066 & 4.978 & 0.000 & $0.186 ; 0.445$ \\
\hline $\mathrm{H}_{2}:$ ATC $\triangle \mathrm{ATB}$ & 0.324 & 0.069 & 4.700 & 0.000 & $0.189 ; 0.455$ \\
\hline $\mathrm{H}_{3}:$ ATA $\triangle \mathrm{ATM}$ & 0.238 & 0.059 & 4.014 & 0.000 & $0.114 ; 0.347$ \\
\hline $\mathrm{H}_{4}:$ ATC $\otimes \mathrm{ATM}$ & 0.248 & 0.082 & 3.020 & 0.003 & $0.075 ; 0.402$ \\
\hline $\mathrm{H}_{5}: \mathrm{ATA} \otimes \mathrm{ATP}$ & 0.232 & 0.072 & 3.213 & 0.001 & $0.077 ; 0.360$ \\
\hline $\mathrm{H}_{6}:$ ATC $\triangle \mathrm{ATP}$ & 0.300 & 0.080 & 3.730 & 0.000 & $0.135 ; 0.448$ \\
\hline $\mathrm{H}_{7}: \mathrm{ATM} \otimes \mathrm{ATP}$ & 0.205 & 0.067 & 3.044 & 0.002 & $0.076 ; 0.343$ \\
\hline $\mathrm{H}_{8}:$ ATP $\triangle \mathrm{ATB}$ & 0.431 & 0.067 & 6.465 & 0.000 & $0.301 ; 0.560$ \\
\hline
\end{tabular}

Baron and Kenny's procedures for mediation analyses, which Zhao et al. (2010) proposed, were used. The results for the serial mediation effect are presented in Table 6. When the findings of the table were examined, the total indirect effects were found to be significant between the attitudes toward the actor/actress and the brand $(\beta=0.121 ; \mathrm{p}<0.01)$, as well as the attitudes toward the character and the brand $(\beta=0.151 ; \mathrm{p}<0.01)$. According to Zhao et al. (2010), the relationship between the attitude toward the actor and character, and the attitude toward the brand, has a complementary mediating effect. The Variance-Accounted-For (VAF) coefficients were calculated for the total indirect effects because indirect effects were detected (Dogan, 2018). As the calculated VAF coefficients between the attitudes toward the actor/ actress and the brand were 0.27 , and 0.32 between the attitudes toward the character and the brand, it can be stated that the attitude toward the movie and product placement has a serial 
mediating effect on the relationship between the attitude toward the actor/actress and the character and the attitude toward the brand. For the model without any mediating variable, $\mathrm{R}^{2}$ of the attitude toward the brand was $31 \%$, while there was an increase of $43 \%$ in $\mathrm{R}^{2}$ for the model with mediating variables, which could be considered as proof of the mediating role of the attitude toward the movie and product placement. In line with these findings, hypotheses $\mathrm{H}_{9}$ and $\mathrm{H}_{10}$ of the research were supported.

Table 6

Results of the Serial Mediation Effect

\begin{tabular}{|c|c|c|c|c|c|}
\hline Constructs & Standardize $\beta$ & Standard Dvt. & t Value & $\mathbf{p}$ & 95\% Confidence Interval \\
\hline $\begin{array}{l}\text { ATA } \triangle \text { ATB } \\
\text { (Total Indirect Effect) }\end{array}$ & 0.121 & 0.039 & 3.110 & 0.002 & $0.051 ; 0.202$ \\
\hline ATA $\triangle \mathrm{ATP} \otimes \mathrm{ATB}$ & 0.100 & 0.036 & 2.764 & 0.006 & $0.036 ; 0.175$ \\
\hline ATA®ATM $\triangle \mathrm{ATP} \triangle \mathrm{ATB}$ & 0.021 & 0.010 & 2.142 & 0.032 & $0.007 ; 0.048$ \\
\hline $\begin{array}{l}\text { ATC } \triangle \mathrm{ATB} \\
\text { (Total Indirect Effect) }\end{array}$ & 0.151 & 0.037 & 4.072 & 0.000 & $0.088 ; 0.238$ \\
\hline ATC $\otimes$ ATP $\otimes$ ATB & 0.129 & 0.038 & 3.410 & 0.001 & $0.063 ; 0.215$ \\
\hline ATC $\triangle A T M \triangle A T P \triangle A T B$ & 0.022 & 0.011 & 1.920 & 0.055 & $0.007 ; 0.055$ \\
\hline
\end{tabular}

\section{Conclusions and Future Directions}

This study, which addressed the attitude toward the actor, character, and movie as attitudinal components that may affect the attitude toward product placement and brand, aimed to explain the effect of the variables that shape the attitudes of the audience toward the brand being placed. Nowadays, consumers' preferences for a movie and TV series viewing platform are shifting toward digital media and service providers that offer ad-free content, so product placement becomes much more critical for brands, as it is a practice that maintains this advantage. Therefore, it is necessary to understand the attitudes of the audience toward product placement and brand and to consider the factors shaping these attitudes in order to create a competitive advantage.

Actors/Actresses can be considered as one of the main variables shaping the audience's attitude toward a movie, as they are an essential element of its box office success (Elberse, 2007). This is an important finding for both production companies and brands because it can be predicted that besides the effect of the actor/actress on the box-office return, its interaction with the brand being placed can indirectly affect the attitude toward the movie and thus the attitude toward the product placement and the brand. For marketers, actors and actresses not only influence the box office success but also shape the audience. Actors and actresses are effective in shaping the attitudes of the audience, recalling, as well as creating a buzz. The audience cannot judge a movie without seeing it; however, the actors may successfully shape 
perceptions of the audience and contribute to the formation of a marketing buzz acting as "connector" between the audience and the movie (Mohr, 2007). Therefore, influential placements, prolonged air-time and visibility often lead to higher levels of brand recall (Brennan et al., 1999; Wilson \& Till, 2011: 394).

The attitude toward the character has a direct effect on the attitude toward the movie, and an indirect effect on the attitude toward the brand. The characteristics of the character in the watched movie or TV series and its relationship with the brand or product being placed affect the attitudes of the audience toward the brand. Especially if the character's attitude toward the product being placed is positive, the character affects the audience's attitude toward the relevant product (Russell \& Stern, 2006). Identifying brands with actors/actresses and characters in movies plays an essential role in increasing credibility for viewers (Morton \& Friedman, 2002). Therefore, a product placement compatible with the character has the potential to create awareness for the relevant brand, and positively affect the brand image. However, the critical point that should be considered for marketing managers is that the image and values created by the characters in the movie or series must be fitted with the brand's values.

Consistent with the findings of Balasubramanian et al. (2014), the general attitudes of the audience toward the movie affect the attitudes toward product placement and thus to the brand. When the audience enjoys a movie or TV series, has a positive approach, or follows a movie series or TV series, their attitudes toward product placement in that movie or TV series are generally affected, thereby causing them to exhibit a similar assessment for the brand.

When the findings of the research were examined, product placement in movies and TV series, as supported by the literature, has an impact on the attitude toward the brand being placed (MacKenzie \& Lutz, 1989; Balasubramanian, 2014). Therefore, in today's intense advertising and competitive environment, it is possible to predict that a brand that is correctly and inconspicuously incorporated into the scenario will create audience awareness and shape their attitudes toward the brand. However, it should be taken into consideration that an audience who has a negative attitude toward product placement can also reason out the relevant brand in this manner. Thus, it is essential to implement a strategic plan for the process. In the light of the aim of the communication strategy, product placements need to be integrated into the overall communications strategy, and integrated into the media plan as a new medium (Russell \& Belch, 2005). Besides, importance should be placed on the fit of actors or characters' images with the brand's image and the meaning transfer between them.

One of the most critical limitations of this research was that the participants were asked to recall and specify information about the movie they have watched in the last week, the brand being placed, the actor/actress, the character and the sector to which the brand belongs. This situation corresponds to a significant limitation for the research, as well as correctly answering specific questions about variables and contributing to finding reliable results for the 
research. The exclusion of surveys with missing information led to the fact that a significant portion of these surveys was also not addressed in this context, although many of them were obtained. Therefore, limited data were studied. Longer time intervals in future research may contribute to a study with more surveys.

Peer-review: Externally peer-reviewed.

Conflict of Interest: The authors have no conflict of interest to declare.

Grant Support: The authors declared that this study has received no financial support.

\section{References}

Argan, M., Velioğlu, M. N., \& Argan, M. (2007). Marka Yerleştirme Stratejilerinin hatırlama üzerine etkisi: 'Gora' filmi üzerine araştırma. Elektronik sosyal bilimler dergisi, 6(19), 159-178. https://dergipark.org.tr/ en/download/article-file/69925

Balasubramanian, S. K. (1994). Beyond advertising and publicity: Hybrid messages and public policy issues. Journal of advertising, 23(4), 29-46. https://www.jstor.org/stable/pdf/4188949.pdf?refreqid=excelsior \%3A122100aa62b55be991df0f2d2c94b685

Balasubramanian, S. K., Karrh, J. A., \& Patwardhan, H. (2006). Audience response to product placements: An integrative framework and future research agenda. Journal of advertising, 35(3), 115-141. https:// www.tandfonline.com/doi/pdf/10.2753/JOA0091-3367350308?needAccess=true

Balasubramanian, S. K., Patwardhan, H., Pillai, D., \& Coker, K.K. (2014). Modeling Attitude Constructs in Movie Product Placements. Journal of product \& brand management, 23(7), 516-531.

Barnhardt, T. M., Manzano, I., Brito, M., Myrick, M., \& Smith, S. M. (2016). The effects of product placement in fictitious literature on consumer purchase intention. Psychology \& marketing, 33(11), 883-898. https:/www.tandfonline.com/doi/pdf/10.2753/JOA0091-3367350308?needAccess=true

Brennan, I., Dubas, K. M., \& Babin, L. A. (1999). The influence of product-placement type \& exposure time on product-placement recognition. International Journal of Advertising, 18(3), 323-337.

Cohen, J. (1988). Statistical power analysis for the behavioral sciences. NJ: Lawrence Erlbaum Associates.

Cowley, E., \& Barron, C. (2008). When product placement goes wrong: The effects of program liking and placement prominence. Journal of Advertising, 37(1), 89-98. https://www.tandfonline.com/doi/abs/10.2753/ JOA0091-3367370107

D'Astous, A., \& Touil, N. (1999). Consumer evaluations of movies on the basis of critics' judgments. Psychology \& marketing, 16(8), 677-694.

Doğan, D. (2018). SmartPLS ile veri analizi. US: Charleston SC.

Deloitte. (2017) Is there and \#adlergic epidemic? Ad blocking across media. Retrieved September 24, 2019 (Available from the Deloitte Web site: https:/www2.deloitte.com/content/dam/Deloitte/global/Images/ infographics/technologymediatelecommunications/gx-deloitte-tmt-2018-adblocking-media-report.pdf)

Elberse, A. (2007). The power of stars: Do star actors drive the success of movies?. Journal of Marketing, 71(4), 102-120. https://www.hbs.edu/faculty/Pages/item.aspx?num=23770

Fornell, C. \& Larcker, D.F. (1981). Evaluating structural equation models with unobservable variables and measurement error. Journal of Marketing Research, 18(1), 39-50. 
Gupta, P. B., \& Gould, S. J. (1997). Consumers' perceptions of the ethics and acceptability of product placements in movies: Product category and individual differences. Journal of Current Issues \& Research in Advertising, 19(1), 37-50. https://www.tandfonline.com/doi/abs/10.1080/10641734.1997.10505056

Hair, J. F., Black, W. C., Babin, B. J., Anderson, R. E. \& Tatham, R. L. (2006). Multivariate Data Analysis. NJ: Pearson Prentice Hall.

Hair, J.F., Tomas, G., Hult, M., Ringle, C.M. \& Sarstedt, M. (2014). A Primer on partial least square structural equations modeling (PLS-SEM). Los Angeles, CA: Sage.

Henseler, J., Ringle, C.M. \& Sarstedt, M. (2015). A New Criterion for Assessing Discriminant Validity in Variance-Based Structural Equation Modelling, Journal of the Academy of Marketing Science, 43, 115135. https://link.springer.com/article/10.1007/s11747-014-0403-8

Horton, D., \& Wohl, R. R. (1956). Mass communication and para-social interaction: Observations on intimacy at a distance. Psychiatry, 19(3), 215-229.

Iqbal, M. (2020). Netflix Revenue and Usage Statistics. Retrieved August 14, 2020 (Available from the Business of Apps Web Site: https://www.businessofapps.com/data/netflix-statistics/)

Jin, C., \& Villegas, J. (2007). The effect of the placement of the product in movie: Consumers' emotional responses to humorous stimuli and prior brand evaluation. Journal of Targeting, Measurement \& Analysis for Marketing, 15(4), 244-255.

Johnstone, E., \& Dodd, C. A. (2000). Placements as mediators of brand salience within a UK cinema audience. Journal of Marketing Communications. 6(3), 141-158. https:/www.tandfonline.com/doi/ pdf/10.1080/13527260050118649

Karrh, J.A., Frith, K.T. \& Callison, C. (2001). Audience attitudes towards brand (product) placement: Singapore and The United States. International Journal of Advertising, 20(1), 3-24. https://www.tandfonline. com/doi/abs/10.1080/02650487.2001.11104874

Karrh, J. A., Mckee, K. B., \& Pardun, C. J. (2003). Practitioners' evolving views on product placement effectiveness. Journal of Advertising Research, 43(2), 138-149.

Kırcova, İ., \& Köse, Ş. (2017). Televizyon dizileri ve filmlerde ürün yerleştirmeye yönelik genç tüketicilerin tutumlarına ilişkin bir nitel araştırma. Pazarlama ve Pazarlama Araştırmaları Dergisi, 19, 51-77. http:// www.pazarlama.org.tr/dergi/yonetim/icerik/makaleler/129-published.pdf

Knoll, J., Schramm, H., Schallhorn, C., \& Wynistorf, S. (2015). Good guy vs. bad guy: The influence of parasocial interactions with media characters on brand placement effects. International Journal of Advertising, 34(5), 720-743.

Kurthakoti, R., Balasubramanian, S. K., \& Altobello, S. (2016). Brand-Character association and attitude toward brands in movie placements. International Journal of Business Administration, 7(2), 43-59.

Kim, T. Y., \& Shin, D. H. (2017). The survival strategy of branded content in the Over-The-Top (OTT) environment: Eye-Tracking \& Q-Methodology approach in digital product placement. Telematics and Informatics, 34(7), 1081-1092.

Mackay, T., Ewing, M., Newton, F., \& Windisch, L. (2009). The effect of product placement in computer games on brand attitude \& recall. International Journal of Advertising, 28(3), 423-438.

McCracken, G. (1989). Who is the celebrity endorser? Cultural foundations of the endorsement process. Journal of Consumer Research, 16(3), 310-321. https:/www.jstor.org/stable/2489512?seq=1\#metadata_info_tab_contents

McKechnie, S. A., \& Zhou, J. (2003). Product placement in movies: A comparison of Chinese \& American consumers' Attitudes. International Journal of Advertising, 22(3), 349-374. https://www.tandfonline. com/doi/abs/10.1080/02650487.2003.11072858 
Mackenzie, S. B., \& Lutz, R. J. (1989). An empirical examination of the structural antecedents of attitude toward the ad in an advertising Pretesting Context. Journal of Marketing, 53(2), 48-65. https://www.jstor. org/stable/1251413?seq=1\#metadata_info_tab_contents

Morton, C. R., \& Friedman, M. (2002). "I saw it in the movies": Exploring the link between product placement beliefs \& reported usage behavior. Journal of Current Issues \& Research in Advertising, 24(2), 33-40. https://www.tandfonline.com/doi/abs/10.1080/10641734.2002.10505133

Mohr, I. (2007). Buzz marketing for movies. Business horizons, 50(5), 395-403.

Muzellec, L., Kanitz, C., \& Lynn, T. (2013). Fancy a coffee with friends in 'central perk'? reverse product placement, fictional brands \& purchase intention. International Journal of Advertising, 32(3), 399-417.

Nelson, M. R., \& Devanathan, N. (2006). Brand placements Bollywood style. Journal of Consumer Behavior: An International Research Review, 5(3), 211-221. https://onlinelibrary.wiley.com/doi/abs/10.1002/cb.173

Newell, J., Salmon, C. T., \& Chang, S. (2006). The hidden history of product placement. Journal of Broadcasting \& Electronic Media, 50(4), 575-594.

Ohanian, R. (1990). Construction \& validation of a scale to measure celebrity endorsers' perceived expertise, trustworthiness, \& attractiveness. Journal of Advertising, 19(3), 39-52. https://www.tandfonline.com/doi/abs/10.1080/00913367.1990.10673191

O'Reilly, D., \& Kerrigan, F. (2013). A view to a brand: Introducing the movie brandscape. European Journal of Marketing, 47(5/6), 769-789. https://www.emerald.com/insight/content/ doi/10.1108/03090561311306868/full/pdf

Patwardhan, H., \& Patwardhan, P. (2016). When fiction becomes fact: Effect of reverse product placement on consumer attitudes. Journal of Promotion Management, 22(3), 349-369.

Phillips, J., \& Noble, S. M. (2007). Simply captivating: Understanding consumers' attitudes toward the cinema as an advertising medium. Journal of Advertising, 36(1), 81-94. https://www.tandfonline.com/doi/abs/10.2753/JOA0091-3367360106

PQMedia (2018). Global Branded Entertainment Marketing Forecast 2018. Retrieved September 24, 2019 (Available from the PQ Media Web Site: https://www. pqmedia.com/product/global-branded-entertainment-marketing-forecast-2018/)

Reklamcilar derneği (2018). Türkiye'de Tahmini Medya ve Reklam Yatırımlart. Retrieved September 24, 2019 (Available from Reklamcilar Derneği Web Site: http://www.rd.org.tr/Assets/uploads/bf6ab5b50d86-4bc3-92a7-da47c165cb61.pdf)

Ringle, C.M., Wende, S. \& Becker, J.M. (2015). SmartPLS 3. Retrieved March 10, 2019 (Available from SmartPls Web Site: www.smartpls.com)

Rubin, R. B., \& McHugh, M. P. (1987). Development of parasocial interaction relationships. Journal of Broadcasting \& Electronic Media, 31 (3), 279-292. https://www.tandfonline.com/doi/ abs/10.1080/08838158709386664

Russell, C. A. (1998). Toward a framework of product placement: Theoretical propositions. Advances in Consumer Research, 25, 357-362. https://www.acrwebsite.org/volumes/8178/volumes/v25/NA-25

Russell, C. A. (2002). Investigating the effectiveness of product placements in television shows: The role of modality \& plot connection congruence on brand memory \& attitude. Journal of Consumer Research, 29(3), 306-318.https://www.jstor.org/stable/10.1086/344432?seq=1\#metadata_info_tab_contents

Russell, C. A., \& Belch, M. (2005). A managerial investigation into the product placement industry. Journal of Advertising Research, 45(1), 73-92. 
Russell, C., \& Stern, B. (2006). Consumption in soap operas from Brazil, New Zealand, \& the US: Production, products, \& process. Advances in Consumer Research, 33, 134-137. https://www.acrwebsite.org/ volumes/12476/volumes/v33/NA-33

Sapmaz, E., \& Tolon, M. (2014). Bütünleşik pazarlama iletişiminde ürün yerleştirme ve üniversite öğrencilerinin televizyon programlarındaki ürün yerleştirmelere ilişkin tutumlarına yönelik bir araştırma. Gazi Üniversitesi İktisadi ve İdari Bilimler Fakültesi Dergisi, 16(2), 15-44. https://dergipark.org.tr/en/pub/gaziuiibfd/issue/28310/300843

Sarstedt, M., Ringle, C.M. \& Hair, J.F. (2017). Partial Least Squares Structural Equation Modelling. In C. Homburg, M.Klarmann \& A.Vomberg (Eds.), Handbook of Market Research (pp. 2-34). Heidelberg: Springer.

Scott, J., \& Craig-Lees, M. (2010). Audience engagement and its effects on product placement recognition. Journal of Promotion Management, 16(1-2), 39-58. https://www.tandfonline.com/doi/ full/10.1080/10496490903571803

Sood, S., \& Drèze, X. (2006). Brand extensions of experiential goods: Movie sequel evaluations. Journal of Consumer Research, 33(3), 352-360. https://www.jstor.org/stable/10.1086/508520?seq=1\#metad ata_info_tab_contents

Srivastava, R. (2011). Brand placement Strategy in a movie song \& its impact on brand's image. The IUP Journal of Brand Management, 8(2), 19-30.

Su, H. J., Huang, Y. A., Brodowsky, G., \& Kim, H. J. (2011). The impact of product placement on tv-induced tourism: Korean TV dramas and Taiwanese viewers. Tourism Management, 32(4), 805-814. https://www. sciencedirect.com/science/article/pii/S0261517710001317

Ulker-Demirel, E., Akyol, A., \& Simsek, G. G. (2018). Marketing and consumption of art products: The movie industry. Arts and the Market, 8(1), 80-98. https:/www.emerald.com/insight/content/doi/10.1108/ AAM-06-2017-0011/full/html

Tsai, M. T., Wen-Ko, L., \& Liu, M. L. (2007). The effects of subliminal advertising on consumer attitudes \& buying intentions. International Journal of Management, 24(1), 3-14.

Tuchman, A. E., Nair, H. S., \& Gardete, P. M. (2018). Television ad-skipping, consumption complementarities \& the consumer demand for advertising. Quantitative Marketing and Economics, 16(2), 111-174. https:/link.springer.com/article/10.1007/s11129-017-9192-y

Westcott, et al. (2020). Digital Media Trends, 14th Edition. Retrieved August 14, 2020 (Available from the Deloitte Web Site: https://www2.deloitte.com/us/en/insights/industry/technology/digital-media-trendsconsumption-habits-survey/summary.html\#)

Williams, K., Petrosky, A., Hernandez, E., \& Page Jr, R. (2011). Product placement effectiveness: Revisited \& renewed. Journal of Management and Marketing Research, 7, 1-24. http://connection.ebscohost. com/c/articles/59782912/product-placement-effectiveness-revisited-renewed

Wilson, R. T., \& Till, B. D. (2011). Product placements in movies and on Broadway: A field study. International Journal of Advertising, 30(3), 373-398.

Zhao, X, Lynch, J.G. ve Chen, Q. (2010). Reconsidering Baron and Kenny: Myths and Truths about Mediation Analysis, Journal of Consumer Research Inc., 37(2), 197-206. 


\section{Appendix A.}

Descriptive Statistics of Constructs

\begin{tabular}{lccccccccc}
\hline & \multirow{2}{*}{ N } & \multirow{2}{*}{ Min. } & \multirow{2}{*}{ Max. } & \multirow{2}{*}{ Mean } & \multirow{2}{*}{ SD } & \multicolumn{2}{c}{ Skewness } & \multicolumn{2}{c}{ Kurtosis } \\
\cline { 8 - 10 } & & & & & & Statistic & Std. Error & Statistic & Std. Error \\
\hline Att. Actor & 300 & 1,00 & 5,00 & 4,0090 &, 79918 &,- 804 &, 141 &, 326 &, 281 \\
Att. Character & 300 & 1,00 & 5,00 & 4,1880 &, 77563 & $-1,291$ &, 141 & 2,193 &, 281 \\
Att. Movie & 300 & 1,00 & 5,00 & 4,3542 &, 85496 & $-1,598$ &, 141 & 2,465 &, 281 \\
Att. Placement & 300 & 1,00 & 5,00 & 3,9475 &, 96031 &,- 969 &, 141 &, 516 &, 281 \\
Att. Brand & 300 & 1,00 & 5,00 & 3,9808 &, 99762 & $-1,097$ &, 141 &, 920 &, 281 \\
Valid N (listwise) & 300 & & & & & & & & \\
\hline
\end{tabular}

